\title{
Legal and Policy Responses to Climate Change-induced Migration and Conflict: Insights from Nigeria
}

\author{
Agu, Helen Ph.D \\ Department of International \& Comparative Law \\ University of Nigeria, Nsukka; AAP Research Scholar, Michigan State University, East Lansing USA \\ helen.agu@unn.edu.ng; aguhelen@msu.edu \\ Onyeabor, Emmanuel Ph.D \\ Department of International \& Comparative Law, University of Nigeria, Nsukka \\ emmanuel.onyeabor@unn.edu.ng \\ Agu, Sussan Ph.D \\ Royal Heritage Ikoyi Lagos, Nigeria \\ sussanaguo@yahoo.com
}

\begin{abstract}
Nigeria has witnessed dramatic climate change impacts in recent years resulting in droughts and desertification in several northern states with fast receding grassland vegetation. This has induced migration especially by pastoral farmers from the semi-arid agro-ecological zones down south towards the Benue trough in search of lush green vegetation for their herds. The result is frequent strife and conflict between these nomadic groups and the sedentary farming communities in the rich Benue River Basin trough, resulting in loss of lives and properties. In recent years, the conflicts have assumed diverse political, religious and socio-cultural dimensions. Using an in-depth desk review of extant literature and policy documents, this paper appraises the policy and regulatory responses to these crises juxtaposing it with climate change mitigation and adaptation measures in Nigeria. We posit that the major causes of conflicts revolve around land ownership for settlement, grazing and farming; that the conflict has assumed ethno-religious colorations with great impact on the socio-economic wellbeing of the inhabitants and migrants. We realize that migration is a form of local level adaptation measure and conflict a directional reaction to these adaptation manifestations which need to be addressed holistically, and therefore propose a comprehensive, all-engaging approach to dealing with this problem by recognizing the cause and effect of this migration and conflict which is climate change. This will inform policy and strategic interventions to address the underlying causes (climate change), and not just the manifestations (migration and conflict).
\end{abstract}

Keywords: Temperature changes, pastoralism, Farmers, Herdsmen, Desertification

DOI: $10.7176 / J L P G / 99-01$

Publication date:July $31^{\text {st }} 2020$

\section{Introduction}

The actual and potential linkages between the environment, climate change, migration and conflicts are critically important for Africa, which is seen as the region of the world most vulnerable to the impacts of climate change. ${ }^{1}$ These linkages between climate change, human migration, and social conflict is seen as harmful and important as it adds to the existing developmental crisis of most developing nations. ${ }^{2}$ These linkages are particularly important to policy makers, donors, non-governmental organizations, parastatals, governments and scientists as it will undoubtedly affect the realization of most of the sustainable development goals especially in relation to poverty eradication (Goal-1), sustainable cities and communities(Goal-11), climate action (Goal-13). ${ }^{3}$

Looking at the linkages between climate change, human migration, and social conflict has traditionally been the purview of other disciplines such as the natural and social sciences, climate sciences, geography and migration studies. ${ }^{4}$ Despite the lack of robust empirical evidence, a growing number of media reports attempt to link climate change to the ongoing violent conflicts in Syria and other parts of the world, as well as to the

\footnotetext{
- Paper presented at the World Forum on Climate Justice, hosted by Elsevier \& Center for Climate Justice, Glasgow-Caledonian University, Glasgow, Scotland, June 19-21, 2019.

${ }^{1}$ Intergovernmental Panel on Climate Change (IPCC) (2007), in Contribution of Working Group II to the Fourth Assessment Report of the Intergovernmental Panel on Climate Change, M.L. Parry, et al., (eds), Cambridge and New York: Cambridge University Press, 2007.

${ }^{2}$ Olakunle Michael Folami and Adejoke Olubimpe Folami, (2013), "Climate Change and Inter-Ethnic Conflict in Nigeria," Peace Review, . 25:1, 104-110, DOI: 10.1080/10402659.2013.759783; See also Akpodiogaga-a, P. and Ovuyovwiroye Odjugo, (2010). “General overview of climate change impacts in Nigeria” Journal of Human Ecology, 29(1):47-55. DOI: 10.1080/09709274.2010.11906248

${ }^{3}$ Sachs, Jeffrey, et al., (2019), "Transformations to Achieve the Sustainable Development Goals", Sustainable Development Report Sustainable Development Solutions Network (SDSN).

${ }^{4}$ Akpodiogaga-a, P. and Ovuyovwiroye Odjugo, (2010), above note 2.
} 
migration crisis in Europe. ${ }^{1}$

A recent study exploiting bilateral data on asylum seeking applications for 157 countries over the period 2006-2015, assessed the determinants of refugee flows using a gravity model which accounts for endogenous selection in order to examine the causal link between climate, conflict and forced migration. The results indicate that climatic conditions, by affecting drought severity and the likelihood of armed conflict, played a significant role as an explanatory factor for asylum seeking in the period 2011-2015.2

Crespo Cuaresma of the Institute of Applied System Analysis (IIASA) and a professor of economics at Vienna University of Economics and Business stated that "the effects of climate change go way beyond pure meteorological changes and have consequences for social and political processes worldwide, and that acknowledging this evidence could take us closer to finding global solutions to the problem". 3

There is no doubt that the world has invested resources in combating climatic hazards yet, the world is experiencing and recovering from a series of climate and environmental-related disasters, such as the Japanese tsunami and nuclear crisis, the Haiti earthquake, the Indian Ocean tsunami, Hurricane Katrina, the Lagos and Ibadan flood, among others, which have killed, displaced millions, and destroyed properties worth millions of dollars. $^{4}$

In light of these impacts, the role of the climate change in social conflicts (including communal, inter-state and non-state conflicts) is receiving increased attention. Conflict resolution experts, in particular, are examining conflicts from a climate and environment lens, aiming to determine causality (if any) and to identify appropriate intervention strategies. ${ }^{5}$ Some conflicts, such as those in Darfur and pastoral migration-induced conflict in Nigeria and the Horn of Africa, are strongly linked by some to the climate and environment, ${ }^{6}$ while others categorise them as predominantly political, ethnic or economic. ${ }^{7}$

While acknowledging the above scientific explorations, and other socio analytical approaches, ${ }^{8}$ this paper however uses a different legal and policy lens to examine the legal and policy responses being adopted in Nigeria as a quick measure towards addressing the outcome of the linkage (conflict) without taking into adequate consideration the underlying 'push' factors which is climate change.

These controversies and climate change predictions demand more critical attention especially with regard to contemporary Nigeria conflicts to unpack underlying influential actors, including climate factors such as temperature, rainfall and sea level rise. ${ }^{9}$ Nigeria as an exemplar of the continent for this discourse because among Africa's 54 recognized countries, Nigeria is unique in her vulnerability to climate change; she is home to the largest human population on the continent at over 203 million people, has more than 250 ethnic groups and an age structure dominated by $0-14$ year old. ${ }^{10}$ Climate change vulnerabilities for Nigeria's populations range depending on changes in desert encroachment, coastal inundations, drying up of surface waters and shifts in crops cultivated over time. ${ }^{11}$

In light of this, the various ways in which climate change can contribute to, or even prevent, climate change-induced migration and conflicts in Nigeria require further investigation. This paper highlights the legal and policy responses to climate change induced migration and conflict in Nigeria and examines key thematic legal and policy implementation issues and concerns. It provides analyses of laws, policies and approaches to

\footnotetext{
1 Abel G, M., et al., (2019), "Climate, conflict and forced migration". Global Environmental Change,. 54: p. 239-249. DOI:10.1016/j.gloenvcha.2018.12.003

${ }^{2}$ Ibid.

${ }^{3}$ Cimons, Marlene, "The effects of Climate Change go way beyond pure meteorological changes and have consequences for social and political processes worldwide", https://www.ecowatch.com_nexus_media, (accessed 13 March, 2020).

4 Odoh, S. I., and F.C. Chilaka, (2012), "Climate change and conflict in Nigeria: a theoretical and empirical examination of the worsening incidence of conflict between Fulani herdsmen and farmers in northern Nigeria," Arabian Journal of Business and Management Review (OMAN Chapter), 2(1):110-124

5 Urmilla Bob, Salomé Bronkhorst, eds., (2014), “Conflict-sensitive adaptation to climate change in Africa, ” Climate Diplomacy Series, 2014.

6 Amusan, L., O. Abegunde and T.E. Akinyemi, (2017), "Climate change, pastoral migration, resource governance and security: the Grazing Bill solution to farmer-herder conflict in Nigeria" Environmental Economics, 8(3): p. 35-45. doi:10.21511/ee.08(3).04; see also Omolo, N., (2010), "Gender and climate change-induced conflict in pastoral communities: Case study of Turkana in northwestern Kenya". African Journal on Conflict Resolution, 10(2): 81-102.

${ }^{7}$ Buhaug H., (2010), "Climate not to blame for African civil wars." Proceedings of the National Academy of Science of the United States of America, 107(38): p. 16477-16482; see also Sunga L. S., (2011), "Does climate change kill people in Darfur?" Journal of Human Rights and the Environment, 2(1): 64-85.

${ }^{8}$ Obioha, E.E., (2008), "Climate Change, Population Drift and Violent Conflict over Land Resources in Northeastern Nigeria" J. Hum. Ecol., 23(4): 311-324; Adekunle, O. A., and S.R. Adisa, (2010) “An Empirical Phenomenological Psychological Study of Farmer-Herder Conflicts in North-central Nigeria" Journal of Alternative Perspectives in the Social Sciences, 2(1), 1-27; Higazi, A., (2016), "Farmer-pastoralist conflicts on the Jos Plateau, central Nigeria: security responses of local vigilante and the Nigerian state " Conflict, Security \& Development, 16(4): p. 365-385.

${ }^{9}$ Higazi, A., ibid.

${ }^{10}$ Central Intelligence Agency (CIA), The World Fact book, https:/www.cia.gov/library/publications/the-world-factbook/ (accessed 24 February, 2020)

${ }^{11}$ Akpodiogaga-a, P. and Ovuyovwiroye Odjugo, (2010), above note 2.
} 
ensure that migration conflicts arising from climate change are addressed and climate change adaptation measures are conflict-sensitive.

\section{The geography and climate change in Nigeria}

Nigeria, a nation of over 150 million people shoehorned into an area twice the size of California and confronting deep ethnic divisions, development challenges (such as paucity of human resources and capital to implement developmental plans and policies). ${ }^{1} \quad$ Nigeria has a history of poor leadership and struggles to meet its resource needs and wants and this failure to share limited resources well underlies many of the violent conflicts that dot the country's social landscape, pitting neighbour against neighbour, Muslim against Christian, patron against the client, citizen against the state. ${ }^{2}$

Nigeria's climate is also likely to see growing shifts in temperature, rainfall, storms, flooding and sea levels throughout the twenty-first century. ${ }^{3}$ These climatic challenges, being unaddressed, has thrown already stressed resources such as farm lands and drinking water into even shorter supply. Moreover, poor responses to resource shortages have serious negative secondary effects, including more sickness and hunger, fewer jobs, and poor economic growth, which in turn opens the door to more violence. ${ }^{4}$ Indeed, in a few conflict-prone spots such as the Middle Belt (eg, Benue, Plateau, Kogi states) and the arid Northeast (eg, Adamawa, Taraba, Borno states), this sequence is probably playing out on a limited scale already. ${ }^{5}$

There is need to consider the potential of climate change to fuel herders' migration induced violence as the country figures out how to adapt. Although paucity of empirical data has clouded the picture of how climate change does affect Nigeria's environment and resource base instigating migration among Fulani herders, and experts are divided over the precise causal links between climatic change and migration induced violence between Fulani herders and indigenous farmers. ${ }^{6}$ However, there is broad agreement that without intelligent, even-handed responses, the impacts of climate change could compound the risks of conflict. ${ }^{7}$ Climate change not only triggers communal conflicts but can engender state failure. In an International Alert publication, ${ }^{8}$ have noted that "threats to international stability associated with climate change, is placing some 40 states at risk of climate induced conflict." Climatic factors have given rise to water related hazards; lack of water causes draughts and excess of water causes floods, high tidal water causes salinity and acidity in soil. ${ }^{9}$

Understanding Nigeria's climate future depends on better country-specific and local-level analysis. ${ }^{10}$ Predictions so far have relied heavily on models for the world or West Africa. The Intergovernmental Panel on Climate Change (IPCC), did identify Nigeria as a climate change "hot spot" likely to see major shifts in weather in the twenty-first century. ${ }^{11}$ Yet, there is a need to examine closer: the country's 350,000 square miles, situated in a tropical belt between the $4^{\circ} \mathrm{N}$ and $14^{\circ} \mathrm{N}, 3^{\circ} \mathrm{E}$ and $15^{\circ} \mathrm{E}$ parallels, span six major vegetation zones, from mangrove-saltwater swamp to montane regions to grasslands to desert. Soils and weather patterns vary widely, and altitudes range from 3,000 feet to less than 10 feet above sea level. For this reason, no single generic model or adaptation scheme could reasonably apply to the whole country. ${ }^{12}$

United States Institute of Peace (USIP) special report on Nigeria ${ }^{13}$ identifies three main types of shifts occasioned by climate change that could ultimately feed into conflict. First, parts of the country- the arid north especially - are facing the one-two punch of more heat and less rain. Parts of Nigeria's northern Sahel area (the transition zone between the Sahara Desert to the north and the grasslands to he south) get less than 10 inches a year already, a full 25 per cent less than thirty years ago. Temperatures can top 105 degrees Fahrenheit and are likely rising. Second, many parts of the country will likely experience more severe weather. Torrential rains and windstorms are becoming harsher and more common across Nigeria. Over the past forty years, for instance, recorded volumes of torrential rains increased 20 per cent across various southern states, some of which already see up to 160 inches of rainfall a year, with wet seasons lasting eight to ten months. ${ }^{14}$ Third, along the southern

\footnotetext{
${ }^{1}$ Sayne A., (2011), "Climate Change Adaptation and Conflict in Nigeria” United States Institute of Peace: Special Report. 274. www.usip.org. (accessed 15 February, 2020)

${ }^{2}$ Adekunle and Adisa, (2010), above note 11 .

${ }^{3}$ Sayne A.,(2011), above note 15 .

4 Ibid.

${ }^{5}$ Ibid.

${ }^{6}$ Ibid.

${ }^{7}$ UN General Assembly, (2009), Report of the Secretary-General: Climate Change and Its Potential Security Implications, New York: United Nations; Akpodiogaga-a, P. and Ovuyovwiroye Odjugo, (2010), above note 2.

${ }^{8}$ Smith, D., and J. Vivekananda, (2007), "A Climate of Conflict: Links between Climate, Peace and War", International Alert. London.

${ }^{9}$ Ubelejit, Nte Timothy, (2016), "Fulani Herdsmen and Communal Conflicts: Climate Change as Precipitator" Journal of Political Science and Leadership Research, 2(1): 4

${ }^{10}$ Akpodiogaga-a, P. and Ovuyovwiroye Odjugo, (2010), above note 2

${ }^{11}$ Boko M.et al., (2007), Climate Change: Impacts, Adaptation, and Vulnerability-Africa, Cambridge: Cambridge University Press

${ }^{12}$ Sayne A.,(2011), above note 15; Akpodiogaga-a, P. and Ovuyovwiroye Odjugo, (2010), above note 2.

${ }^{13}$ Sayne, A.,(2011, ibid.

${ }^{14}$ Boko M.et al., (2007), above note 25.
} 
coastline, sea levels could rise 1.5 to 3 feet by century's end-a further increase over the nearly 1 -foot rise observed in the last fifty years. ${ }^{1}$

The report also relates that Nigeria's poor adaptive response to these climatic shifts to leads to serious resource shortages. ${ }^{2}$ Existing data isolate two possible resource shortages under status quo levels of response to climate change, ${ }^{3}$ and these are in the area of land scarcity and water shortage. As it relates to land scarcity, most of the northern states of Nigeria, such as Bauchi, Borno, Gombe, Jigawa, Kano, Kaduna, Katsina, Kebbi, Sokoto, Yobe, and Zamfara states, are already experiencing intense widespread desertification as a result of increasing sand dunes. ${ }^{4}$ In relation to water resource shortage, USIP report notes that more heat plus less rain is already creating drought conditions in parts of northern Nigeria. ${ }^{5}$ There is also shortage of drinking water for household use principally due to poor management and government supply failures. Many rural household depend more on harvested rainwater for consumption. ${ }^{6}$ Government data show rural households harvest rain for more than half their total water consumption and northern groundwater tables have dropped sharply over the last half-century, owing partly to less rain. ${ }^{7}$ Flooding, in parts of southern Nigeria, caused by sea level rise is also contaminating freshwater aquifers, rivers, and stock-watering points, leaving them with high salinity and more polluted with sediment and sewage. ${ }^{8}$

Following poor climate change adaptive responses to the resource shortage identified above, other secondary impacts are evident and these include decrease in the county's public health profile, more hunger, more human displacement, less economic growth and its attendant unemployment. ${ }^{9}$ Shortage of available land for farming as well as water resources leads to food crisis which in turn results to hunger, sicknesses and death. Human migration is a rational drive imposed by acute resource shortage. Most pastoral farming communities are in the Sahel zone which has been taken over by desertification thereby compelling them to migrate towards coastal areas in search of pasture and water for their herds. ${ }^{10}$ As Flavell aptly stated that " in the initial stages of environmental degradation, migration can signify a logical and lawful livelihood diversification alternative. It is an adaptation approach for affected people to mitigate the effects of environmental hazards and climate change... when environmental degradation becomes severe...migration can become permanent and may require relocation of affected populations, either internally or in another country". ${ }^{11}$ This happens often in Plateau State, Benue State, Taraba State etc. The summary of the report is that change shifts leads to the shortage of critical natural resources, such as land and water, with overreaching secondary impacts ultimately feed into conflict.

\section{Climate change-induced migration and conflict in Nigeria}

Most researches that has been carried out on mechanisms potentially turning migration (in the case of Nigeria, Fulani herdsmen) into a cause of conflict in receiving areas focuses on the herders' role in the spread of violence. ${ }^{12}$ Empirical evidence on increased conflict potentials in receiving areas (North-East, Middle East, South-South and South East Nigeria) is rather ambiguous, especially with regard to the exact mechanisms at play. ${ }^{13}$ Salehyan identified three broad conflict-generating mechanisms:

1. Resource competition between refugees and local communities,

(In Nigeria's case: Competition between the Fulani herders and the farmers over controversial grazing routes, land, destruction of farm crops, etc)

2. Ethnicity and cultural differences between refugees and local communities and

(In Nigeria's case: the incompatibility in cultural values and norm thereby leading to almost impracticable coexistence between the Fulani herdsmen and the host communities)

3. Refugees as active or passive resources for parties of the conflict in cases where refugee camps are used as a recruitment base or hiding ground for combatants.

(In Nigeria's case: Instances where the Fulani herdsmen are accused of providing cover for mercenaries, militants and marauders from across Northern Africa who can easily be used to carry out vengeful acts of violence on farmers or resisting communities)

In sum, there is statistically significant evidence for an increase in the onset of conflict by one-third in receiving

\footnotetext{
${ }^{1}$ Odjugo, P., (2005), “An Analysis of Rainfall Pattern in Nigeria” Global Journal of Environmental Science, 4,2: $139-45$.

${ }^{2}$ Sayne A.,(2011), above note 15.

${ }^{3}$ DFID/ERM, (2009), Impact of Climate Change on Nigeria's Economy, DFID: Abuja.

${ }^{4}$ Federal Ministry of Environment, (2008), National Policy on Desertification and Drought, Federal Ministry of Environment, Abuja

${ }^{5}$ Sayne A.,(2011), above note 15.

${ }^{6}$ Ibid.

${ }^{7}$ National Bureau of Statistics, Social Statistics, 2009. Abuja.

${ }^{8}$ Federal Ministry of Environment, (2008), above note 32.

${ }^{9}$ Sayne A., (2011), above note 15 .

${ }^{10}$ Ubelejit, Nte T., (2016), above note 23.

${ }^{11}$ Flavell, Alex, (2010), Migration, Environment and Climate Change: Training Manual, Geneva, IOM Development Fund.

12 Odoh, S. I., and F.C. Chilaka, (2012), above note 7; Obioha, E.E., (2008) above note 11; Ubelejit, Nte T., (2016), above note 23.

${ }^{13}$ Salehyan I., (2008), "From climate change to conflict? No consensus yet" Journal of Peace Research, 45(3): 315-326.
} 
communities in Nigeria hosting large numbers of violent rampages from confrontational Fulani herdsmen. ${ }^{1}$

It is becoming apparent that the twin effects of climate change viz drought and desertification, which has continued unabated and encroaching at an alarming rate in northern Nigeria has contributed to gradual decline in crop yield and high animal mortality rate since $1970 \mathrm{~s}^{2}$ Since agricultural sector constitutes Nigeria's biggest employer of labor, on which over $75 \%$ of northern Nigerians depend for their subsistence, low yield in crop production and high mortality rate of farm animals results in loss of livelihood and hence poverty. Given these conditions, there has been disaffection for farming and massive population migration in two distinct directions. ${ }^{3}$ First, southwards migration of Fulani herdsmen and their animals in search of greener pasture and water. These have occasioned the recurring herder-farmer conflict in northeastern states in Nigeria. Second, rural to urban migration of the youth farmers in search for better life. ${ }^{4}$ This migration is central to the unending conflict in northern Nigeria and the emergence of groups like Boko Haram. These migrant youths lack formal education and skills vital for survival in the urban areas. Being unable to gain employment due to poor governance and absence of social welfare scheme, these youth easily turn to crime and become a terror to the society. ${ }^{5}$

Undoubtedly, these migrations would generate discontent, attrition and conflicts in the receiving communities. The case of Fulani herdsmen is a perfect illustration of such migrations. Because of persistent droughts and desertification in the Northern part of Nigeria, most Fulani herdsmen have migrated South in search of green pastures for their cattle and these migrations have been causing many violent conflicts for the host communities. ${ }^{6}$ Invariably climate change is a great facilitator of communal conflicts; this potential is to a reasonable extent determined by migration and other variables like attitude of the immigrants on the one hand and perception, reception, response and cordial relationship with host communities on the other hand. ${ }^{7}$ Often, violent conflict is very unlikely because of the need to compete for scarce natural resources.

Another implicating factor in climate change induced migration and conflict in Nigeria is the shrinking Lake Chad. This is responsible for influx of migrants from neighboring countries. ${ }^{8}$ The Lake Chad is encircled by four countries of Nigeria, Cameroon, Niger and Chad while the greater part of its shorelines is made up of marshes. Also, the Lake Chad Basin Commission (LCBC) which is an inter-governmental organization that oversees water and other natural resource usages in the basin drew its membership from eight countries of Cameroon, Chad, Niger, Nigeria, Algeria, the Central African Republic, Libya, and Sudan due to their proximity to Lake Chad. ${ }^{9}$ It was estimated that 12 per cent of the over 400 million people in these countries live around the lake and depended on it for crop and livestock farming, fishing, commerce and trade. With 90 per cent of the lake's water coming from the Chari River, its initial size was estimated to be about 400,000 sq by $4000 \mathrm{BC}$. By January 15, 2007, the lake had shrunk to $500 \mathrm{sq}$. km, signifying over 90 per cent decline from its normal size. This has further affected the agricultural livelihood of about 5 million Nigerians and Chadians already battered by the insurgency. Experts have attributed the shrinking to overgrazing, population growth, climate change and insecurity that led to a decline in vegetation and increased desertification. ${ }^{10}$ However, Okeke ${ }^{11}$ stated that United Nations (UN) Office for the Coordination of Humanitarian Affairs (OCHA) Nigeria hinted that about 7 million people across the Lake Chad basin struggling with food insecurity needed assistance.

\section{Climate change adaptation policy and legal responses in Nigeria}

The Northern region of Nigeria has been the hardest hit by the apparent rising air temperature and declining rainfall in the last five decades having witnessed less than 10 inches rainfall within this period. ${ }^{12}$ Unfortunately, the level of the impact of climate change on this region remains largely unclear, due in part to inadequate national country-specific analysis of changes in climate. ${ }^{13}$ Considering the report of the Intergovernmental Panel on Climate Change which predicted less rainfall for West African interior, including Nigeria by 2100, the fate of

\footnotetext{
${ }^{1}$ Ibid., see also UN General Assembly Report, (2009) above note 21; Ubelejit, Nte T., (2016), above note 23.

${ }^{2}$ Onyia C.,(2015), "Climate Change and Conflict in Nigeria: The Boko Haram Challenge " American International Journal of Social Science, . 4, 2.

${ }^{3}$ Ibid.

${ }^{4}$ Ubelejit, Nte T., (2016), above note 23.

5 Boko M.et al., (2007), above note 28.

${ }^{6}$ Ubelejit, Nte T., (2016), above note 23.

${ }^{7}$ Ibid.

${ }^{8}$ Okeke, C., (2018), "Shrinking Lake Chad and Challenges Ahead Resuscitation” https://leadership.ng/2018/08/21/shrinking-lake-chad-andchallenges-ahead-resuscitation/. (Accessed 21 March 2020).

${ }^{9} \mathrm{Ibid}$.

${ }^{10}$ UNDP Africa, (2016), "Disaster Risk Reduction and Climate Change: Addressing radicalization and violent extremism through climate action." https://www.undp.org/content/undp/en/home/blog/2016/11/14/Enfrentando-la-radicalizaci-n-yel-extremismo-violento-a-trav-s-de-la-acci-n-clim-tica.html. (Accessed 21 March 2020)

${ }^{11}$ Okeke C., (2018), above note 49.

12 Onyia C., (2015), above note 43.

${ }^{13}$ Onyia C., (2015), above note 43.
} 
people living in this region, in the absence of governments' intervention is gloomy. ${ }^{1}$

According to the IPCC, states respond to changes in climate by either mitigation, or adaptation or both. Adaptation refers inter alia to adjustments in ecological-social-economic systems in response to actual or expected climatic stimuli, their effects or impacts; by building a climate-resilient society that is able to withstand or recover quickly from difficult conditions caused by the adverse effects of climate change is most pertinent to Nigeria. ${ }^{2}$ It involves a complex set of actions that requires carefully designed and adroitly executed policies that coordinate economic-technological, political-institutional and structural-legal or informational structures of a state in a way that reduces its vulnerability, and enhances its capacity to overcome environmental challenges associated with changes in climate. ${ }^{3}$

Nigeria's adaptive capacity to changing climate has been a major concern to many and a focus of scrutiny in recent times. Reports indicate that, while there may have been some adaptation policy initiatives, they are hardly developed, insufficient, and inefficient. ${ }^{4}$ The Nigerian constitution assigned greater responsibility vis-àvis climate change adaptation to the states and state actors. Chapter 2, Article 28 of the Constitution of the Federal republic of Nigeria (CFRN, 1999) stipulates that the state shall protect and improve the environment and safeguard the water, air and land, forest, and wildlife of Nigeria. ${ }^{5}$ This, of course, is statement of policy which requires state actors to devote substantial resources, including administrative structures, legal frameworks, finance, knowledge, technology, information and administration as would necessitate accomplishing. ${ }^{6}$ Nevertheless, this has scarcely been so.

More so, despite the constitutional framework for realizing above stated goals, which allocates various responsibilities to each tier (federal, state and local government) and levels (executive, legislator and judiciary) of government, ${ }^{7}$ their activities are rarely collaborative or coordinated. ${ }^{8}$ Similarly, adaptation policies, including the 'National Policy on Drought and Desertification; Draught Preparedness Plan, 2007; National Policy on Erosion, Flood Control and Coastal Zone Management 2005; and National Biodiversity Strategy and Action Plan, 2004', have at best remained well articulated on paper. Lacking both the technicalities and political will to create and support requisite institutional framework needed to carry out these policies, their activities have barely gone beyond mere rhetoric. ${ }^{9}$ The Special Climate Change Unit (SCCU), charged with the responsibility of coordinating the activities of Inter-ministerial Committee on Climate Change; with members drawn from various ministries, including Non-Governmental Agencies (NGOs) and academic. This, with the Centre for Climate Change and Fresh Water Resources, Federal University of Technology Minna; Centre for Energy, Research and Development, Obafemi Awolowo University Ile-Ife; and Abubakar Tafawa Balewa University, Bauchi, remains the primary institution for climate change adaptation in Nigeria. ${ }^{10}$ However, lack of funds and gross mismanagement greatly impinged on the capacity of this institution to perform optimally. Hence, the observation that even the capacity of SCCU to drive and coordinate national climate change response is weak; and the fact that there are very few people with proven competencies in the unit and that facilities remain inadequate speaks volumes. ${ }^{11}$

With regard to legal responses to climate change induced migration and conflict in Nigeria, it is noteworthy that the livestock sector in Nigeria accounts for as much as $3.2 \%$ of Nigeria's GDP. ${ }^{12}$ However, the apparent absence of government recognition of the sector continues to impede the optimization of its potentials and hence it remains riddled with local strives. There are no clearly demarcated grazing lands, which could provide rangelands and passageways (cattle corridors) in order to allow livestock to access water points and pastures without causing damage to cropland. Hence, the spate of violence which has erupted in different parts of the country, especially in the north central region, as a result of conflict between migrant pastoral farmers and their host communities indicates government's acknowledgment of the need to revisit extant laws in order to halt growing tension between pastoralists and their hosts. ${ }^{13}$

Legal and policy responses by successive government over the years have been inconsistent. For instance, without due cognizance to regional variations in agricultural traditions marked by conflicting patterns of natural

\footnotetext{
1 Niang, I., et al., (2014), “Africa" in Climate Change 2014: Impacts, Adaptation, and Vulnerability, https://www.ipcc.ch/site/assets/uploads/2018/02/WGIIAR5-Chap22 FINAL.pdf (accessed 24, February 2020).

${ }^{2}$ Ibid.; IPCC, (2007) above note 1.

${ }^{3}$ Ibid.

${ }^{4}$ Onyia C., (2015), above note 43.

${ }^{5}$ Constitution of the Federal Republic of Nigeria (CFRN), 1999 (as amended in 2011), Cap C1, Laws of the Federation. 2004.

${ }^{6}$ Federal Ministry of Environment, (2008), above note 32.

${ }^{7}$ CFRN 1999, above note 59, ss. 4-6.

${ }^{8}$ Onyia C., (2015), above note 43.

${ }^{9}$ Sayne A., (2011), above note 15

${ }^{10}$ Federal Ministry of Environment, (2009), Nigeria and Climate Change: Road to Cop15, Federal Ministry of Environment: Abuja

${ }^{11}$ Onyia C., (2015), above, note 43.

${ }^{12}$ Fabusoro, E. and A. Oyegbami, (2009), "Key issues in the livelihoods security of migrant Fulani pastoralist: empirical evidence from Southwest Nigeria," Journal of humanities social sciences and creative arts, 4(2), p. 1-20;

${ }^{13}$ Amusan, L., O. Abegunde and T.E. Akinyemi, (2017) above note 9.
} 
resource use between arable and pastoral farming systems, the Land Use Act of 1978 granted equal access to both traditions in any part of the country. ${ }^{1}$ Under that legal framework, the Federal government held the right to redraw the boundaries between cattle routes, range lands and farm lands accordingly and envisaged peaceful coexistence of various groups. However, this right has not exercised by successive governments due to political oppositions. Also under the National Agricultural Policy of 1988, it was stipulated that a minimum of $10 \%$ of the national territory, that is, 9,8 million acres, be allocated to grazing reserves. However, only $2.82 \%$ was acquired out of 313 reserves. $^{2}$

The National Grazing Route and Reserve Commission Bill of 2011 was an attempt to establish grazing routes and reserves across the 36 states of Nigeria and the FCT. ${ }^{3}$ In July 03, 2012, 'The National Grazing Route and Reserve Bill' was presented to the Nigerian Senate for deliberation. ${ }^{4}$ There were divisions among lawmakers on the legality of the Federal Government's step to appropriate lands from any state of the federation for use as grazing reserve, and this stalled the passage of the Bill at its third reading. ${ }^{5}$ While some have argued that the government's and the upper house' failure to enact a law to establish grazing reserves indicates poor commitment to finding a lasting solution to the conflict, ${ }^{6}$ public opinion particularly among host communities show apprehension towards legalizing land-grabbing and culture clash between migrants and their hosts.

Many states of the federation have resorted to sedentarization as a strategy for preventing conflict between farmers and pastoralists ${ }^{7}$ There is hardly any state in Nigeria where migrant herders, mostly of the Fulani extraction, do not have a sedentary settlement and these impose greater challenge in regards feeding and maintaining the herds when compared with the regular pastoral system. Nonetheless, most countries in west with highly developed livestock production systems run a sedentarized system in ranches. While this system could halt the recurrent violent conflict as plays out in Nigeria, it is also a very intensive system in which basic requirements that will encourage pastoralists to settle in designated areas need to be in place in various parts of the country. ${ }^{8}$

Much of the discourse on conflict between the two largest agricultural traditions in Nigeria has been conditioned by the fragile relations among the country's many ethnic and religious groups, as well as economic and political interests of the elite. ${ }^{9}$ It is therefore safe to argue that the climate change induced migration and conflict in Nigeria a convergent mix of nature and culture which becomes confounded and aggravated by the combined effects of ecological, political, religious, ethnic or economic tensions. As such, any attempt at reversing this trend of violent conflict in Nigeria could factor in the historical and political dimensions of the contestations. $^{10}$

The priority on a legislative solution is seen in the number of processes ongoing in the area of grazing laws at the federal and state legislatures. A 2013 Bill before the Nigerian Senate - the upper arm of the two houses of the country's National Assembly entitled 'Bill for an Act to provide for the Establishment, Preservation and Control of National Grazing Reserves and Livestock Routes and the Creation of National Grazing Reserve Commission and for purposes connected therewith.' Similarly, another Bill designed on the same issues was considered at the House of Representatives, the lower house of the National Assembly. The Bill in the lower house sought that power be granted to a federal commission to acquire lands from all the state governments and the Federal Capital Territory to establish grazing routes and reserves for Fulani herders. Subject to the directives of the Commission, Fulani herdsmen would have a right to such lands, despite the wishes of the owners, and despite the wishes of the government of any state. ${ }^{11}$

These pieces of legislation has generated political tension, which is further amplified by the complex diversity of the Nigerian state. ${ }^{12}$ For example, while the Bills elicited optimism among the people of the north and received strong support from lawmakers of Northern extraction, it was vehemently opposed by legislators from Southern Nigeria, and some from central Nigeria. In addition to these legislative divides, several

\footnotetext{
${ }^{1}$ Muhammed, I., A. B. Ismaila and U.M. Bibi, (2015), “An assessment of farmer-pastoralist conflict in Nigeria using GIS" International Journal of Engineering Science Invention, 4(7): p. 23-33 ${ }^{2}$ Ibid.

3 Kumolu, C., (2014), "Fulani herdsmen, farmers clashes: furore over grazing reserve". Vanguard News, http://www.vanguardngr.com/2014/04/fulani-herdsmen-farmersclashes-furore-grazing-reserves/\%20 (accessed 24, February 2020)

4 Daily Trust, Nigeria: "Grazing Reserves Commission Bill Divides Senate" 4 July 2012. http://allafrica.com/stories/201207040466.html\%20 (accessed on 1 May 2020).

${ }^{5}$ Ibid.

${ }^{6}$ Oriola E. O. and Alabi, M.O., (2014), "Assessing River Basin System Potentials To Enhance Sustainable Irrigation Farming Operations

And Management In Nigeria," Journal of Environmental Research And Development, 2014. 8 (3), January-March 2014

${ }^{7}$ Amusan, L., O. Abegunde and T.E. Akinyemi, (2017) above note 9.

${ }^{8}$ Kumolu, C., (2014) above note 70.

${ }^{9}$ Amusan, L., O. Abegunde and T.E. Akinyemi, (2017) above note 9

${ }^{10}$ ibid

${ }^{11}$ Okeke, O. E., (2014), "Conflicts between Fulani Herders and Farmers in Central and Southern Nigeria: Discourse on Proposed Establishment of Grazing Routes and Reserves," International Journal of Arts and Humanities, 3(1), 66-84

12 Ibid.
} 
associations representing the interests of different ethnic groups in Southern and Central Nigeria inclu(de the Ijaw National Congress, the Federation of Middle Belt Peoples, Afenifere (a Yoruba organization), the Movement for the Survival of Ukwuani People and the Southern Kaduna in Diaspora have publicly opposed the Bill. ${ }^{1}$ A number of issues have been raised on both sides of the divide. ${ }^{2}$ On the supporting line of thought, Grazing Bill proponents justify the Bill on a number of grounds. First is the fact that cattle herders need pasture for their cattle and since they are Nigerians, they are constitutionally allowed to reside and carry out their activities in any part thereof. Second, they contend that environmental change manifested particularly through desertification has led to a drastic decline in the supply of pasture in the Northern region. This, coupled with overgrazing as a result of the ever growing size of herds, has rendered the environment unsustainable. They therefore attribute conflict to the forced migration to the south as herders are compelled by environmental and demographic forces to seek alternative sources of pasture. Oftentimes environment-induced population movements occur without recourse to national borders. ${ }^{3}$ It is in the course of migratory adaptation according to this line of argument that herders often come into conflict with farming communities. ${ }^{4}$ As a strategy for preventing such recurrent conflicts, the Bill suggest that the federal government designates grazing routes and reserves across the 36 states of the federation regardless of the cultural and agricultural characteristics of the localities. ${ }^{5}$ By implication, they seek rights for Fulani herdsmen to have access to take possession of lands found suitable in any part thereof within Nigeria including those situated in non-Fulani communities for the purpose of cattle grazing. This proposal has received support from pro-fulani interests. ${ }^{6}$ Quite a good number of stakeholders including state governors see the Grazing Bill proposals as an option for peace in the affected states. From an opposing point of view, civil society groups and indigenous groups have been most vocal in rejecting the Grazing Bill. According to Amusan et al, this position has been hinged on a number of arguments. One is that the Bill would deprive indigenous peoples of lands which otherwise would have been used for purposes suitable to the local agricultural practices and livelihood systems. ${ }^{7}$ Second, critics argue that such a redistribution of land would deprive the natives of farm lands and render families landless, since such lands were traditionally transferred as inheritance from one generation to another. Others contend that acquisition of land for grazing across the nation was a part of its effort to advance the expansionist agenda of the Fulani who are historically associated with Islamic Jihad. It is likely that, once entrenched on reserves, the Fulani would seek to acquire more and, contrary to the express purpose of the Bill; more conflicts will result between herders and natives over land. It is also argued that southern Nigeria has much less land than the northern region and its available land faces greater population pressure from its higher population density when compared to the north. ${ }^{8}$

In reaction to this tension and incessant violent conflicts, most states in the north central Nigeria like Benue and Kogi states' legislature enacted their anti-grazing laws which bans open grazing by migrant pastoralists, titled Open Grazing Prohibition and Establishment of Ranches Law of 2017.

\section{Towards a holistic approach to climate change-induced migration and conflict: the way forward}

In the face of the ravages of climate change on the ecology of Nigeria and its observable impact on national security and developmental strides, we suggest the following measures to ensure a holistic approach towards curtailing the conflict situation in Nigeria.

\subsection{Addressing the Lake Chad Basin Factor}

The depressing truth is that the Lake Chad Basin Commission has not been effective. It was set up by the four neighbouring countries as early as 1964 , but it was not funded properly and faces various other challenges. It was supposed to regulate the use of water and other natural resources in the Chad Basin and coordinate development projects and research. ${ }^{9}$ Today, the most urgent action is to increase the volume of water in Lake Chad, which could be done by improving the management of the entire watershed of the Chad basin. This would include reviewing the management of regional vegetation ${ }^{10}$ It is encouraging to note that the Muhammadu Buhari administration is committed to tackling the issues of climate change. It has signed the Paris Agreement on climate action and has begun to draft and implement related policies. The legislature is working on legislation

\footnotetext{
Ibid.

${ }^{2}$ Amusan, L., O. Abegunde and T.E. Akinyemi, (2017) above note 9.

${ }^{3}$ Amusan, L., (2013), "Nigeria and its Neighbors in the Age of Climate Change: An Assessment of the Lake Chad Basin Area," in A. A. Akinsanya and J. A. Ayoade (eds), (2013), An Introduction to Political Science in Nigeria,. Lanham. Maryland: University Press of America, p. 261-282

${ }^{4}$ Nzeshi, O., "Grazing Reserves Bill: The Challenges Ahead" This Day, August 10, 2013.

${ }^{5}$ Okeke, O. E., (2014), above note 78 .

${ }^{6}$ Nzeshi, O.. (2013), above note 83.

${ }^{7}$ Amusan, L., O. Abegunde and T.E. Akinyemi, (2017) above note 9.

${ }^{8}$ Ibid.

${ }^{9}$ Okeke C., (2018), above note 49.

${ }^{10}$ Ibid.
} 
to mainstream all related issues. ${ }^{1}$

The government of the other four neighbouring countries should show more commitment to see to the revitalization of the Chad Basin. The LCBC should be adequately funded to perform its functions effectively

\subsection{Reviving River Basin Development Authorities}

Successive governments in Nigeria have adopted different strategies and programme to develop the rural areas because majority of people in the country live and find their livelihood in the rural areas. One of such strategies adopted was the establishment of River Basin and Rural Development Authorities (RBRDAs). ${ }^{2}$ A river basin is a complex system with various resources for developmental projects and programmes. This is the basis on which the Federal Government of Nigeria established 11 River Basin Development Authorities (RBDA) in the 70s. The 1979 River Basin Development Authorities Act established 12 river basins authorities within the countries four large river basins. The basin authorities spread across the 36 states of the Federation. The mandate of the Basin Authorities were to provide water for irrigation and domestic water supply, improve navigation, hydro-electric power generation, recreation facilities and fisheries projects. Others include engender plantation farming and encourage industrial complexes that could bring the private and public sectors in joint business partnership. ${ }^{3}$ The lower and Upper Benue River Basins and Rural Development Authorities, just like other River Basins in the nation were established by the Federal Government of Nigeria to bring development to their host communities through the creation of employment opportunities, augmenting income of rural dwellers and the provision of social amenities. ${ }^{4}$ The RBDAs embarked on programs and projects to boost agricultural product through mechanization and the development of water resources potentials of the nation. These functions entailed direct agricultural production, construction of dams, dykes, polders, drilling of boreholes for potable water supply and construction of rural roads and bridges to link project sites. Federal Government should assist and as well support the Lower and Upper Benue River Basin Authorities to partake actively in agricultural activities since the RBRDAs are quite close to rural farmers. ${ }^{5}$

The RBDA project is a critical area which is a vital adaptive strategy has been neglected over the years due to poor funding and apparent neglect. Revamping the RBDAs in the northern states of Nigeria will harness the full potential of RBDAs to turn around the debilitating effects of climate induced drought and desertification. ${ }^{6}$ [43]. Farmers and herders will have access to adequate water supply for their crops, livestock and livelihood and hence discourage migration in search of greener pastures and consequently curb resulting conflict.

\subsection{Grazing Routes Option}

The current migration, conflict and crisis experienced in different parts of Nigeria today are obviously being compounded by scarcity of water and herds destroying harvests. ${ }^{7}$ The Federal Government has responded to the clashes with a proposal to recreate grazing routes that herders used across the country in the 1960 s. ${ }^{8}$ The proposal has triggered a political backlash, however, as it is considered to pander to the herdsmen. Critics say it would only exacerbate problems of land ownership, as the grazing routes of the 1960s no longer exist in a more densely populated country today. Some argue that nomads should not roam around with cattle but switch to ranching. For example, Dickson Tarkighir, a member of Nigeria's House of Representative from Benue State, points out that ranching would ensure that the herdsmen get access to facilities such as hospitals, veterinary doctors and schools. ${ }^{9}$ The big questions, of course, are on what land ranches might be established and who might provide the water they would need? These are right based and justice issues which can only be addressed holistically by paying attention the causal and implicating factors of climate change.

\subsection{Inclusive Regulation}

To overcome the challenges faced by the bid to reopen grazing routes and the controversies stalling national legislation on open grazing in Nigeria, there is an opportunity for the government to consider the principle of inclusiveness in any legislation aimed at curbing migration and conflict. ${ }^{10}$ Existing legal responses have been shrouded by political, cultural and religious diversities which have bedeviled the nation in recent times. There is

\footnotetext{
${ }^{1}$ Ibid.

${ }^{2}$ Ogundele, Adeolu Tunde, (2019), "River Basin Development Authorities in Nigeria: The Neglected Tools for National Development"

International Journal of Advanced Academic Research | Sciences, Technology and Engineering |5(3). ISSN: 2488-9849.

${ }^{3}$ Oriola E. O. and Alabi, M.O., (2014), above note 73.

${ }^{4}$ Oravee, A., (2015), "Lower and Upper Benue River Basin and Rural Development Authorities and Rural Development: A Comparative

Study" Research on Humanities and Social Sciences, 2015.5(13). www.iiste.org

${ }^{5}$ Ogundele, Adeolu Tunde, (2019), above note 91.

${ }^{6}$ Oravee, A., (2015), above note 93.

${ }^{7}$ Ubelejit, Nte T., (2016), above note 23.

${ }^{8}$ Amusan, L., O. Abegunde and T.E. Akinyemi, (2017) above note 9.

${ }^{9}$ Ibid.

${ }^{10}$ Amusan, L., O. Abegunde and T.E. Akinyemi, (2017) above note 9.
} 
an opportunity to consider the contentions for and against the present regulatory efforts of the state and federal legislature. Environmental regulation remains a constitutional responsibility of both states and the federal government. ${ }^{1}$ The Federal government should not oust the jurisdiction of states to enact laws prohibiting open grazing and demand for ranching by insisting on the controversial National grazing bill or by insisting that state legislature should repeal their laws. ${ }^{2}$ Such act can only endanger progress towards climate change adaptation, future environmental justice and perpetuate the already existing migration related conflict.

\subsection{Education and Awareness}

Climate change impacts are ideally understood by the affected communities for any meaningful adaptation strategies and policies to be effective. ${ }^{3}$ Information sharing is very vital for citizen participation in climate change governance. The farmers whether pastoral or farm based, need to understand the implicating factors of climate change and be aware of its ramifications, whether as a temporal set back or a long term irreversible change. ${ }^{4}$ This vital information could trigger off local level adaptation programmes and help them make wholesome decisions. The communities affected by environmental migrants if armed with vital information, could become more tolerant and accommodating and this may even engender peaceful coexistence devoid of violence. ${ }^{5}$ The climate change institutions such as the SCU and its sister agencies share the responsibility of engaging relevant stakeholders for the creation of awareness and dissemination of information. Both public and private media organizations, civil society, non-governmental and faith-based organization should be involved.

\section{Conclusion}

The consequences of climate change on human and ecological security in Nigeria is far reaching. A series of inter-ethnic, inter-religious, and reprisal attacks in the country have been traced to be as a result of unfavorable climatic conditions in the northern parts of the country. This paper has highlighted the ecological variations occurring in the unique geographical space of Nigeria especially in the relation to the Northern part of Nigeria. It identifies the climatic change shifts which creates shortage of critical natural resources such as land and water and how these create secondary impacts leading to migration and consequently, conflict.

The threat of desertification and drought resulting from low adaptive responses fuels the migration of nomadic or pastoral herdsmen towards the southern part of Nigeria and the reactionary stance of receiving communities' results often in violent conflict. The policy and legal responses by successive Nigerian government has not been effective enough to stem the tide of this conflict due to ethnic, religious and political diversities of the Nigerian state. Having in view that migration is a form of local level adaptation (or a survival strategy) and that conflict is a directional reaction to these adaptation manifestations (or a defense strategy), the paper concludes by suggesting a holistic approach beyond and including law and policy making. Legal and policy options can only thrive when there is an informed appreciation of the letters and intents of the policies and legislation. This can hardly be expected given the multi-ethno-cultural and multi-religious inclinations in the different parts of Nigeria which often is being exploited by the political elite for their selfish political interests. This is where education and public enlightenment becomes critical so that government programmes and intentions can be better appreciated.

This paper, however, does not draw an empirical line of causation in the matrix of climate change, migration and conflict in Nigeria. Drawing lines of causation between climate change and migration-related conflict in specific areas of Nigeria calls for caution, however, particularly as the scientific, social, economic, and political implications of the country's changing climate are still poorly understood. The government needs to initiate a serious program of research and policy discussion before taking major adaptive steps.

Government and private actors also need to ensure that particular adaptive responses do not themselves fuel violence but actively help build peace. Successful adaptation measures will be crosscutting in design and impact, based on inclusive planning and implementation, steer clear of political patronage traps, and confront political and scientific uncertainty.

Solid engagement on the part of the Nigerian federal government is key to achieving the best outcomes. Thus far, official responses have been weak. Along with better information and discussion, Nigeria needs a main federal oversight body to coordinate research and policy, larger roles for sister agencies, and an implementation plan. The country also needs and deserves the help of more developed nations in the form of both adaptation funding and technical assistance.

Future research focus should explore an empirical connection between climate change stress and continued population movement not just within Nigeria but also across the West African region in order to establish a

\footnotetext{
${ }^{1}$ CFRN 1999, above note 59

${ }^{2}$ Oriola E. O. and Alabi, M.O., (2014), above note 73

${ }^{3}$ Sayne A., (2011), above note 15 .

${ }^{4}$ Amusan, L., O. Abegunde and T.E. Akinyemi, (2017) above note 9

${ }^{5}$ Okeke, O. E., (2014), above note
} 
baseline data for future policy direction and strategic planning. Continued research and funding towards an intervention at the Lake Chad Basin and 'greening' of the Sahel will significantly address the problem of water stress and desertification in Norther Nigeria. 